\title{
Subclinical leukopenia in a cross section of Nigerian blood donors
}

\author{
This article was published in the following Dove Press journal: \\ Journal of Blood Medicine \\ 13 May 201 I \\ Number of times this article has been viewed
}

\author{
Zaccheaus A Jeremiah' \\ Ruth E Umoh ${ }^{2}$ \\ Teddy C Adias ${ }^{3}$ \\ 'Haematology and Blood Transfusion \\ Science Unit, Department of Medical \\ Laboratory Sciences, College \\ of Health Sciences, Niger Delta \\ University, Bayelsa State, Nigeria; \\ ${ }^{2}$ Department of Haematology and \\ Blood Transfusion, University of Port \\ Harcourt Teaching Hospital, Port \\ Harcourt, Nigeria; ${ }^{3}$ College of Health \\ Technology, Ogbia, Bayelsa State, \\ Nigeria
}

Background: Most studies on blood donors are centered on the selective evaluation of red blood cell parameters with little or no regard to white blood cells and platelets.

Methods: One hundred and twelve male blood donors comprising 43 first-time and 69 regular blood donors, drawn from a tertiary health facility in the Niger Delta of Nigeria, participated in the study. Their hematological parameters were assessed using a 3-part differential autohematology analyzer (PCE-210 N).

Results: Of the blood donors, $18.8 \%$ were found to be anemic (packed cell volume $[\mathrm{PCV}]<33 \%$ ) while $12.5 \%$ were leukopenic (white blood cell [WBC] count $<2.0 \times 10^{9} / \mathrm{L}$ ). The leukopenia observed in this study was largely due to the significant reductions in both the absolute lymphocyte $(P=0.019)$, percent lymphocyte $(P=0.016)$, and percent monocyte count $(P=0.008)$. Anemia was obviously due to the reduction in the red blood cell $(\mathrm{RBC})$ count, $\mathrm{PCV}$, hemoglobin $(\mathrm{Hb})$, mean cell $\mathrm{Hb}(\mathrm{MCH})$, and red cell distribution width (RDW) values. Significant positive correlations were found between PCV and total WBC count $(r=0.309$; $P<0.01)$ while a negative correlation was found between PCV and absolute lymphocyte counts $(r=-0.191 ; P<0.005)$ and RDW $(r=-0.219 ; P<0.05)$. Comparison of the mean values of the first-time versus regular blood donor parameters revealed that six parameters were significantly reduced in the regular blood donors (PCV, absolute WBC count, percent monocytes, RBC count, $\mathrm{Hb}, \mathrm{PCV})$. The reference ranges of hematological parameters for Port Harcourt donors are also presented in this study. No thrombocytopenia was observed.

Conclusion: Regular blood donation not only affects red cell parameters but also those of white cells. Subclinical leukopenia is present among regular blood donors in this locality. First-time blood donors would be most preferable when the concentrated white blood cell component of blood needs to be prepared.

Keywords: anemia, leukopenia, hematological indices, blood donors, Nigeria

\section{Introduction}

Blood donation is an essential part of blood transfusion services. In 1997, the World Health Organization set a target for all blood donors to be unpaid volunteers. ${ }^{1}$

In most countries, strict regulations have been established for the selection of blood donors that incorporate criteria that serve to protect both the donor and recipient, ${ }^{2}$ but these regulations are not adhered to in most developing countries, including Nigeria. An acceptable frequency of donation is normally two or three times a year or every 12 weeks. $^{3}$ The effect of frequent blood donation on body iron stores has been studied exhaustively, with very similar findings for iron deficiency and iron deficiency anemia. ${ }^{4-6}$ 
Voluntary unpaid blood donation is a humanitarian act by the healthy to benefit the sick. Commercial donors commonly masquerade as family replacement donors and thus may donate blood more frequently than they should. Since no blood transfusion service can survive without blood donors, the well-being and health of blood donors is an issue of prime importance.

Much emphasis has been laid on iron deficiency, probably because of anemia which reduces maximum oxygen consumption and maximum work performance in proportion to its severity. Since whole blood is composed of three cellular elements (red blood cells, white blood cells, and platelets), parameters other than red blood cells (RBCs) also need to be assessed, which is the aim of this study.

\section{Materials and methods Study population}

The subjects comprised 120 unselected consecutive whole blood donors comprising regular and first-time donors. The first-time donors were mostly patient relatives who were donating blood for the first time. The regular donors had donated blood three to four times prior to the time of collection of study samples. The subjects comprised 112 males and only 8 females. The female group was therefore excluded from the study population because of their small number. The male donors were randomly selected as long as they were eligible for blood donation based on their packed cell volume (PCV) at a cut-off value of 33\%. Age of blood donors ranged from 20 to 60 years. The study was conducted at the blood bank of the University of Port Harcourt Teaching Hospital, Port Harcourt, Nigeria. Donors were bled in the phlebotomy unit after receiving their informed consent. The study received ethical approval from the Hematology department of the same hospital. The survey was conducted between January and May 2010.

\section{Sample collection}

Three milliliters of blood was collected into an EDTA bottle. Blood samples were analyzed the same day or the next day depending on the time of collection (donors who came later in the day had their samples analyzed the next day). Samples held overnight were refrigerated at $2^{\circ} \mathrm{C}$ to $8^{\circ} \mathrm{C}$.

\section{Sample analysis}

Samples were analyzed with a hematology auto analyzer (PCE-210 N; Erma, Inc, Tokyo, Japan), a fully automatic blood cell counter that measures 18 blood component parameters including three white blood cell (WBC) components (lymphocytes, granulocytes and monocytes). Procedures were performed according to the standard operating manual.

\section{Statistics}

Data were analyzed using SPSS software (v 16; SPSS, Inc, Chicago, IL). Descriptive statistics for means, standard deviation, median, and 95\% confidence interval were used. Student's $t$-test was used for the comparison of means between two groups. Probability value was set at alpha 0.05 . Values $\leq 0.05$ were regarded as statistically significant.

\section{Results}

Donors $>40$ years of age $(57.1 \%)$ were most highly represented, with regular donors dominating the study population $(61.6 \%)$ (Table 1); $84.8 \%$ of donors were $\mathrm{O}$ blood group and $92.0 \%$ were $\mathrm{RhD}$ positive.

Table 2 shows reference ranges of hematological parameters in relation to age groups and donor categories. Significant reductions were observed in the following parameters for regular blood donors: PCV $(P=0.001)$, WBC count $(P=0.02)$, other white cells $(\%)(P=0.005), \mathrm{RBC}$ count ( $P=0.012), \mathrm{Hb}(P=0.001)$, and mean corpuscular volume $(\mathrm{MCV})(P=0.03)$. No significant changes were observed for the other parameters (Table 3 ).

Of the 112 blood donors, 21 (18.8\%) were anemic (PCV of $\leq 33 \%$ ) (Table 4). Circulating lymphocytes $(\%)$, granulocytes, and other white cells (monocytes) were significantly lower in the anemic group $(P=0.005$, $P=0.02, P=0.016$, respectively). Total WBCs declined significantly from $4.1 \pm 1.8 \times 10^{9} / \mathrm{L}$ in the anemic group $(P=0.047)$. Similarly, RBC, $\mathrm{Hb}$, and mean cell $\mathrm{Hb}(\mathrm{MCH})$

Table I Characteristics of the male blood donors

\begin{tabular}{lll}
\hline Variables & Number & Percentage (\%) \\
\hline Age (years) & & \\
$\quad<30$ & 29 & 25.9 \\
$30-40$ & 19 & 17.0 \\
$>40$ & 64 & 57.1 \\
Category of donors & & \\
$\quad$ First time & 43 & 38.4 \\
Regular & 69 & 61.6 \\
ABO blood group & & \\
A & 8 & 7.2 \\
B & 9 & 8.0 \\
AB & 0 & 0 \\
O & 95 & 84.8 \\
Rhesus blood group & & \\
RhD negative & 9 & 8.0 \\
RhD positive & 103 & 92.0 \\
\hline
\end{tabular}


Table 2 Reference ranges of the hematological values of the 112 blood donors in relation to their age groups

\begin{tabular}{|c|c|c|c|}
\hline \multirow[t]{3}{*}{ Parameters } & \multirow[b]{2}{*}{$<30(n=29)$} & \multicolumn{2}{|l|}{ Age groups (years) } \\
\hline & & \multirow{2}{*}{$\frac{30-40(n=19)}{\text { Mean (SD); } 95 \% \mathrm{Cl}}$} & \multirow{2}{*}{$\frac{>40(n=64)}{\text { Mean }(S D) ; 95 \% \mathrm{Cl}}$} \\
\hline & Mean (SD); 95\% Cl & & \\
\hline PCV (\%) & 38.0 (4.0); 36.5-39.6 & $36.0(7.8) ; 36-40$ & 39.4 (4.9); 37-4I.7 \\
\hline WBC $\left(\times 10^{9} / L\right)$ & 3.9 (I.9); 3.2-4.6 & 3.9 (1.9); 3.4-4.3 & 4.1 (I.8); 3.2-4.9 \\
\hline Lymphs (abs) & $2.3(0.9) ; 1.9-2.7$ & 2.2 (0.07); I.9-2.4 & $2.1(0.8) ; 1.7-2.5$ \\
\hline Lymphs (\%) & $46.4(10.0) ; 42.6-50.3$ & 51.1 (13.6); 47.7-54.5 & 49.0 (9.1); 44-53.4 \\
\hline Granulocytes (abs) & $1.9(0.9) ; 1.6-2.3$ & $3.5(3.1) ; 0.2-6.8$ & $1.9(0.8) ; 1.5-2.3$ \\
\hline Granulocytes (\%) & 44.5 (II .2); 40.2-48.8 & 39.6 (II.4); 36.7-42.4 & 42.1 (II.I); 36.7-47.5 \\
\hline Monocytes (abs) & $0.7(0.5) ; 0.4-0.9$ & $0.7(0.6) ; 0.5-0.8$ & $0.5(0.5) ; 0.2-0.8$ \\
\hline Monocytes (\%) & $7.7(2.9) ; 6.6-8.9$ & $8.5(5.2) ; 7.2-9.8$ & 8.1 (3.8); 6.2-9.9 \\
\hline $\mathrm{RBC}\left(\times 10^{12} / \mathrm{L}\right)$ & $5.1(1.1) ; 4.6-55$ & $5.0(1.3) ; 4.7-54$ & $5.4(0.9) ; 4.9-5.8$ \\
\hline $\mathrm{Hb}(\mathrm{g} / \mathrm{dL})$ & $13.2(2.0) ; 12.4-13.9$ & 12.9 (3.0); 12.2-13.7 & $13.2(2.0) ; \mid 2.2-14.2$ \\
\hline $\mathrm{MCV}(\mathrm{fL})$ & 73.4 (8.8); 70.1-76.8 & 71.3 (II.6); 68.4-74.2 & 71.3 (II.4); 65.8-76.9 \\
\hline $\mathrm{MCH}(p g)$ & 22.7 (4.2); $21-24.3$ & 22.4 (94.2); 21.3-23.4 & 23.9 (4.0); 65.8-76.9 \\
\hline $\mathrm{MCHC}(\mathrm{g} / \mathrm{dL})$ & 30.2 (4.0); 28.4-32.0 & $34.0(4.0) ; 23-44$ & 3I.I (3.9); 29.2-33.0 \\
\hline RDW (\%) & 16.5 (2.2); 15.7-17.4 & 18.1 (4.I); $17.1-19.1$ & $16.4(2.3) ; 15.3-17.5$ \\
\hline PLT $\left(\times 10^{9} / L\right)$ & 218.1 (74.9); 189.6-246.6 & 249.4 (I I 0.1$) ; 221-276.9$ & 232 (79.4); 193-270.4 \\
\hline MPV (\%) & 7.5 (I.4); 7.0 & 7.4 (I.7); 7.0 & $7.5(1.6) ; 6.7$ \\
\hline PDW (\%) & $36.3(7.6) ; 33.4-39.2$ & 35.8 (9.5); 33.4-38.I & 39.0 (I0.9); 33.7-44.3 \\
\hline
\end{tabular}

Abbreviations: $\mathrm{Cl}$, confidence interval; $\mathrm{Hb}$, hemoglobin; $\mathrm{MCH}$, mean cell hemoglobin; $\mathrm{MCHC}$, mean cell hemoglobin concentration; $\mathrm{MCV}$, mean corpuscular volume; MPV, mean platelet volume; PCV, packed cell volume; PDW, platelet distribution width; PLT, platelets; RBC, red blood cell; RDW, red cell distribution width; SD, standard deviation; WBC, white blood cell.

was significantly lower while the red cell distribution width (RDW) was significantly higher in the anemic group $(P=0.001)$.

Subclinical leukopenia in this study was defined using a cutoff value of total WBC count (absolute) of $<2.0 \times 10^{9} / \mathrm{L}$. Fourteen (12.5\%) of the study population were leukopenic. PCV $(P=0.001)$, WBC count $(P=0.001)$, absolute lymphocytes $(P=0.019)$, percent lymphocytes $(P=0.016)$, percent granulocytes $(P=0.05)$, percent monocytes $(P=0.0080), \mathrm{RBC}(P=0.014), \mathrm{Hb}(P=0.002), \mathrm{MCH}$ $(P=0.001)$, and mean platelet volume (MPV) $(P=0.005)$ were significantly lower in leukopenic donors (Table 5 ).

Significant negative correlations were found between PCV and absolute lymphocytes $(r=0.191)$, PCV and RDW

Table 3 Comparison of mean values of first-time and regular blood donors

\begin{tabular}{|c|c|c|c|c|}
\hline \multirow[t]{2}{*}{ Parameters } & \multirow{2}{*}{$\frac{\text { First time }(n=43)}{\text { Mean } \pm \text { SD }(\text { range })}$} & \multirow{2}{*}{$\frac{\text { Regular }(n=69)}{\text { Mean } \pm \text { SD (range) }}$} & \multirow[t]{2}{*}{ t-value } & \multirow[t]{2}{*}{$P$-value } \\
\hline & & & & \\
\hline$\overline{\mathrm{PCV}(\%)}$ & $41.0 \pm 7.1$ & $30.5 \pm 5.5$ & 3.642 & $0.00 I^{* * *}$ \\
\hline WBC $\left(\times 10^{9} / L\right)$ & $4.4 \pm 1.7$ & $3.6 \pm 1.8$ & 2.367 & $0.02 *$ \\
\hline Lymphs (abs) & $2.3 \pm 0.9$ & $2.1 \pm 0.9$ & 0.677 & $0.50^{\mathrm{ns}}$ \\
\hline Lymphs (\%) & $4.3 \pm 1.0$ & $1.9 \pm 1.1$ & 1.249 & $0.110^{\mathrm{ns}}$ \\
\hline Granulocytes (abs) & $48.0 \pm 11.8$ & $50.5 \pm 12.3$ & 1.050 & $0.296^{\mathrm{ns}}$ \\
\hline Granulocytes (\%) & $41.8 \pm 12.1$ & $40.9 \pm 11.1$ & 0.386 & $0.70 \mathrm{I}^{\mathrm{ns}}$ \\
\hline Monocytes (abs) & $0.6 \pm 0.5$ & $0.6 \pm 0.6$ & 0.155 & $0.07^{\mathrm{ns}}$ \\
\hline Monocytes (\%) & $9.7 \pm 4.6$ & $7.3 \pm 4.0$ & 2.883 & $0.005 * *$ \\
\hline $\mathrm{RBC}\left(\times 10^{12} / \mathrm{L}\right)$ & $5.5 \pm 1.2$ & $4.9 \pm I . I$ & 2.565 & $0.012^{* *}$ \\
\hline $\mathrm{Hb}(g / d L)$ & $14.1 \pm 3.1$ & $12.4 \pm 2.0$ & 3.431 & $0.001 * * *$ \\
\hline $\operatorname{MCV}(\mathrm{fL})$ & $74.7 \pm 9.6$ & $70.1 \pm 11.3$ & 2.194 & $0.03 * *$ \\
\hline $\mathrm{MCH}(\mathrm{pg})$ & $23.6 \pm 3.6$ & $22.1 \pm 4.4$ & 1.867 & $0.06^{\mathrm{ns}}$ \\
\hline $\mathrm{MCHC}(\mathrm{g} / \mathrm{dL})$ & $34.0 \pm 4.0$ & $30.1 \pm 4.0$ & 0.658 & $0.513^{\mathrm{ns}}$ \\
\hline RDW (\%) & $17.0 \pm 3.4$ & $17.7 \pm 3.6$ & 0.94 & $0.34^{\mathrm{ns}}$ \\
\hline $\operatorname{PLT}\left(\times 10^{9} / \mathrm{L}\right)$ & $220.1 \pm 98.2$ & $249.7 \pm 96.0$ & 1.570 & $0.119^{\text {ns }}$ \\
\hline MPV (\%) & $7.6 \pm 1.2$ & $7.4 \pm 1.8$ & 0.423 & 0.673 \\
\hline PDW (\%) & $36.8 \pm 10.0$ & $36.2 \pm 8.9$ & 0.345 & $0.73 I^{\mathrm{ns}}$ \\
\hline
\end{tabular}

Abbreviations: $\mathrm{Hb}$, hemoglobin; $\mathrm{MCH}$, mean cell hemoglobin; $\mathrm{MCHC}$, mean cell hemoglobin concentration; MCV, mean corpuscular volume; MPV, mean platelet volume; PCV, packed cell volume; PDW, platelet distribution width; PLT, platelets; RBC, red blood cell; RDW, red cell distribution width; SD, standard deviation; WBC, white blood cell. 
Table 4 Hematological changes in anemic blood donors

\begin{tabular}{|c|c|c|c|c|}
\hline \multirow[t]{3}{*}{ Parameters } & \multirow{2}{*}{$\begin{array}{l}\text { Anemic } \\
n=2 I\end{array}$} & \multirow{2}{*}{$\frac{\text { Nonanemic }}{n=91}$} & \multirow[t]{3}{*}{$t$-value } & \multirow[t]{3}{*}{$P$-value } \\
\hline & & & & \\
\hline & Mean \pm SD & Mean \pm SD & & \\
\hline PCV (\%) & $30.0 \pm 4.5$ & $40.1 \pm 5.4$ & 7.932 & $0.001 * *$ \\
\hline WBC $\left(\times 10^{9} / L\right)$ & $3.2 \pm 1.6$ & $4.1 \pm 1.8$ & 2.008 & $0.047^{*}$ \\
\hline Lymphs (abs) & $2.1 \pm 1.0$ & $2.2 \pm 0.9$ & 0.661 & 0.510 \\
\hline Lymphs (\%) & $56.1 \pm 16.5$ & $48.0 \pm 10.4$ & 2.835 & $0.005^{* *}$ \\
\hline Granulocytes (abs) & $1.6 \pm 0.9$ & $3.1 \pm 1.1$ & 0.620 & 0.536 \\
\hline Granulocytes (\%) & $36.0 \pm 14.7$ & $42.5 \pm 10.3$ & 2.360 & $0.02 *$ \\
\hline Monocytes (abs) & $0.5 \pm 0.4$ & $0.6 \pm 0.6$ & 1.264 & 0.209 \\
\hline Monocytes (\%) & $6.1 \pm 2.5$ & $8.7 \pm 4.7$ & 2.452 & $0.016 *$ \\
\hline $\mathrm{RBC}\left(\times 10^{\%} / \mathrm{L}\right)$ & $4.1 \pm 1.2$ & $5.3 \pm 1.1$ & 4.604 & $0.001 * *$ \\
\hline $\mathrm{Hb}(\mathrm{g} / \mathrm{dL})$ & $10.5 \pm 1.9$ & $13.6 \pm 2.4$ & 5.393 & $0.001 * *$ \\
\hline $\mathrm{MCV}(\mathrm{fL})$ & $74.9 \pm 9.2$ & $71.2 \pm 11.1$ & 1.405 & 0.163 \\
\hline $\mathrm{MCH}(\mathrm{pg})$ & $20.7 \pm 4.2$ & $23.2 \pm 4.0$ & 2.447 & $0.016 *$ \\
\hline $\mathrm{MCHC}(\mathrm{g} / \mathrm{dL})$ & $26.8 \pm 4.8$ & $3.8 \pm 3.5$ & 0.954 & 0.342 \\
\hline RDW (\%) & $19.8 \pm 4.4$ & $16.9 \pm 3.0$ & 3.557 & $0.001 * *$ \\
\hline PLT $\left(\times 10^{9} / \mathrm{L}\right)$ & $255.0 \pm 112.6$ & $234.5 \pm 93.9$ & 0.870 & 0.386 \\
\hline MPV (\%) & $7.9 \pm 2.4$ & $7.4 \pm 1.4$ & 1.224 & 0.224 \\
\hline PDW (\%) & $34.3 \pm 10.2$ & $36 \pm 9.11$ & 1.149 & 0.253 \\
\hline
\end{tabular}

Notes: *Significant at $P<0.05$; **significant at $P<0.01$.

Abbreviations: $\mathrm{Hb}$, hemoglobin; $\mathrm{MCH}$, mean cell hemoglobin; $\mathrm{MCHC}$, mean cell hemoglobin concentration; MCV, mean corpuscular volume; MPV, mean platelet volume; PCV, packed cell volume; PDW, platelet distribution width; PLT, platelets; RBC, red blood cell; RDW, red cell distribution width; SD, standard deviation; WBC, white blood cell.

( $r=-0.219)$, WI3C and percent lymphocytes $(r=0.285)$, WBC and other white blood cells (monocytes) $(r=0.330)$, and MCV and platelet count $(r=0.309)$. MCH was correlated negatively with RBC $(r=0.226)$, platelets $(r=-0.347)$, and MPV $(r=-0.240)$ (Table 6). MPV was correlated negatively with absolute granulocytes $(r=-0.288)$ and percent granulocytes $(r=-0.316)$. None of the blood donors were thrombocytopenic at a cutoff value of $100 \times 10^{9} / \mathrm{L}$.

\section{Discussion}

This study describes the reference ranges of hematology parameters in blood donors and the effect of regular blood donation on these parameters. Reference ranges were established using samples derived from anonymous blood donors. Out of the 120 blood donors, only 8 (6.6\%) were females. Because this ratio fell outside the Clinical Laboratory Standard Institute (CLSI) guidelines of 120 subjects, ${ }^{7}$ females were excluded from the analysis. The lower proportion of females is likely due to their less frequent participation in blood drives and other medical research because of cultural issues. Hematology ranges derived in this study were comparable to published values in other African countries. ${ }^{8,9}$ This study presents the reference values for males only for the reason mentioned above. Since most donors are males, it is necessary for their reference ranges to be established in a given locality in order to assist in the donor selection procedures. RBC parameters and platelet findings were consistent with those of other published African countries. ${ }^{5,8-11}$

In this study, the RBC parameters PVC, RBC count, $\mathrm{Hb}$, and $\mathrm{MCV}$ values of the regular blood donors were significantly lower than those of first-time blood donors. Also, the proportion of apparently healthy blood donors who were anemic accounted for 21/112 (18.8\%) at a cutoff value of $\mathrm{Hb}<11.0 \mathrm{~g} / \mathrm{dL}$. This proportion was slightly higher than the $13.7 \%$ reported recently by Jeremiah and Koate. ${ }^{5}$ Similarly, the findings of this study are consistent with those of Jeremiah and Koate, ${ }^{6}$ in that the hematological parameters of $\mathrm{Hb}, \mathrm{PCV}$, and $\mathrm{MCH}$ concentration were all lower in the regular donors than in the other categories of donors.

The difference in these findings is probably due to the different study locations: the University of Port Harcourt Teaching Hospital and the Braithwaite Memorial Specialist Hospital. Despite the differences in the prevalence of anemia, it has been established that prevalence of anemia is high in Port Harcourt regular blood donors. The implication of this finding is that these categories of blood donors are likely to compromise their iron stores due to frequent blood donation and thus become iron deficient. Jeremiah and Koate ${ }^{5}$ established the presence of both iron deficiency $(20.6 \%)$ as assessed by serum ferritin level $(<12 \mathrm{ng} / \mathrm{mL})$ and iron deficiency anemia $(12.0 \%)$ as assessed by $\mathrm{Hb}(<11.0 \mathrm{~g} / \mathrm{dL}+$ serum ferritin $<12 \mathrm{ng} / \mathrm{mL}$ ). It could be deduced that most of our regular blood donors are iron deficient, which is not conducive for a supply of good quality blood.

A typical whole blood donation is the equivalent of burning approximately 650 calories. The donated plasma is replaced after two to three days, while RBCs are replaced by bone marrow into the circulatory system at a slower rate, an average of 36 days in healthy adult males. These replacement rates are the basis of how frequently a donor can give blood. ${ }^{12}$ The exact rate of how often a donor can donate blood differs from country to country. RBCs are the limiting step for whole blood donations and the frequency of donation permitted varies widely: Hong Kong 3 to 6 months, ${ }^{13}$ Australia 12 weeks, ${ }^{14}$ the United States 12 weeks, ${ }^{15}$ and the UK usually 16 weeks. ${ }^{16}$ In Nigeria, it is not yet established how often a blood donor can give blood. With the reference values established and the prevalence of anemia known, how many times a donor can give blood in Nigeria needs to be defined.

A donor generally donates approximately $450 \mathrm{~mL}$ of blood at the time of donation. One gram of $\mathrm{Hb}$ contains $3.4 \mathrm{mg}$ of iron. In a normal individual with $15 \mathrm{~g} / \mathrm{dL}$ of $\mathrm{Hb}$, 
Table 5 Hematological changes in leukopenic blood donors

\begin{tabular}{|c|c|c|c|c|}
\hline \multirow[t]{3}{*}{ Parameters } & \multirow{3}{*}{$\begin{array}{l}\frac{\text { Leukopenic }}{\mathrm{n}=14} \\
\text { Mean } \pm \text { SD }\end{array}$} & Nonleukopenic & \multirow[t]{3}{*}{$t$-value } & \multirow[t]{3}{*}{$P$-value } \\
\hline & & $\mathrm{n}=98$ & & \\
\hline & & Mean \pm SD & & \\
\hline PCV (\%) & $32.7 \pm 6.1$ & $39.0 \pm 6.2$ & 3.502 & $0.00 I^{* *}$ \\
\hline WBC $\left(\times 10^{9} / L\right)$ & $1.2 \pm 0.5$ & $4.3 \pm 1.6$ & 7.141 & $0.00 I^{* *}$ \\
\hline Lymphs (abs) & $1.6 \pm 0.9$ & $2.3 \pm 0.9$ & 2.376 & $0.019^{*}$ \\
\hline Lymphs (\%) & $2.2 \pm 1.7$ & $2.9 \pm 1.5$ & 0.276 & $0.78 \mathrm{I}$ \\
\hline Granulocytes (abs) & $55.8 \pm 20.1$ & $48.5 \pm 10.0$ & 2.447 & $0.016 *$ \\
\hline Granulocytes (\%) & $35.9 \pm 19.1$ & $42.0 \pm 9.8$ & 1.905 & $0.05^{*}$ \\
\hline Monocytes (abs) & $0.6 \pm 0.7$ & $0.7 \pm 0.6$ & 0.178 & 0.859 \\
\hline Monocytes (\%) & $5.2 \pm 2.3$ & $8.6 \pm 4.5$ & 2.702 & $0.0 I^{*}$ \\
\hline $\mathrm{RBC}\left(\times 10^{12} / \mathrm{L}\right)$ & $4.3 \pm 1.2$ & $5.2 \pm 1.2$ & 2.492 & $0.014^{*}$ \\
\hline $\mathrm{Hb}(\mathrm{g} / \mathrm{dL})$ & $11.0 \pm 2.5$ & $13.3 \pm 2.5$ & 3.153 & $0.002^{* *}$ \\
\hline MCV (fL) & $68.1 \pm 11.3$ & $72.4 \pm 10.7$ & 1.390 & 0.167 \\
\hline $\mathrm{MCH}(\mathrm{pg})$ & $18.1 \pm 2.7$ & $23.4 \pm 3.9$ & 4.768 & $0.00 I^{* *}$ \\
\hline $\mathrm{MCHC}(\mathrm{g} / \mathrm{dL})$ & $25.8 \pm 4.9$ & $33.5 \pm 3.2$ & 0.853 & 0.396 \\
\hline RDW (\%) & $18.2 \pm 2.9$ & $17.3 \pm 3.6$ & 0.853 & 0.396 \\
\hline PLT $\left(\times 10^{9} / L\right)$ & $226 \pm 72.1$ & $240.1 \pm 100.8$ & 0.492 & 0.624 \\
\hline MPV (\%) & $8.6 \pm 2.4$ & $7.3 \pm 1.4$ & 2.868 & $0.005^{* *}$ \\
\hline PDW (\%) & $37.4 \pm 8.7$ & $36.3 \pm 9.4$ & 0.415 & 0.192 \\
\hline
\end{tabular}

Notes: *Significant at $P<0.05$; **significant at $P<0.01$.

Abbreviations: $\mathrm{Hb}$, hemoglobin; $\mathrm{MCH}$, mean cell hemoglobin; MCHC, mean cell hemoglobin concentration; MCV, mean corpuscular volume; MPV, mean platelet volume; PCV, packed cell volume; PDW, platelet distribution width; PLT, platelets; RBC, red blood cell; RDW, red cell distribution width; SD, standard deviation; WBC, white blood cell.

Table 6 Observed positive correlations of the various hematological parameters using Pearson's correlation test

\begin{tabular}{|c|c|c|}
\hline & Parameters correlated & Correlation coefficient (r) \\
\hline \multirow[t]{6}{*}{$\mathrm{PCV}$} & vs TWBC & $0.309 * *$ \\
\hline & vs Lymphs (abs) & $-0.191 *$ \\
\hline & vs $\mathrm{Hb}$ & $0.895 * *$ \\
\hline & vs $R B C$ & $0.637^{* *}$ \\
\hline & vs RDW & $-0.219 *$ \\
\hline & vs PDW & $0.218^{*}$ \\
\hline \multirow[t]{7}{*}{ WBC } & vs Platelets & $0.276 * *$ \\
\hline & vs Lymphs (abs) & $0.444^{* *}$ \\
\hline & vs Lymphs(\%) & $0.285^{* *}$ \\
\hline & vs Monocytes (abs) & $0.330 * *$ \\
\hline & vs Monocytes (\%) & $0.496 * *$ \\
\hline & vs $\mathrm{Hb}$ & $0.303^{* *}$ \\
\hline & vs RDW & $0.189 *$ \\
\hline \multirow[t]{2}{*}{ MCV } & vs Platelets & $0.309 * *$ \\
\hline & vs MPV & $0.236 *$ \\
\hline \multirow[t]{5}{*}{$\mathrm{MCH}$} & vs PCV & $0.269 * *$ \\
\hline & vs $R B C$ & $0.226 *$ \\
\hline & vs HGB & $0.266^{* *}$ \\
\hline & vs Platelets & $0.347^{* *}$ \\
\hline & vs MPV & $0.240^{*}$ \\
\hline \multirow[t]{4}{*}{ MPV } & vs Granulocytes (abs) & $0.288^{* *}$ \\
\hline & vs Lymphocytes (abs) & $0.267^{* *}$ \\
\hline & vs Granulocytes (\%) & $-0.316 * *$ \\
\hline & vs $\mathrm{MCHC}$ & $0.190 *$ \\
\hline
\end{tabular}

Notes: **Correlation significant at $P<0.01$; *correlation significant at $P<0.05$. Abbreviations: $\mathrm{Hb}$, hemoglobin; $\mathrm{MCH}$, mean cell hemoglobin; $\mathrm{MCHC}$, mean cell hemoglobin concentration; MCV, mean corpuscular volume; MPV, mean platelet volume; PCV, packed cell volume; PDW, platelet distribution width; PLT, platelets; RBC, red blood cell; RDW, red cell distribution width; SD, standard deviation; TWBC, total white blood cell.
$100 \mathrm{~mL}$ of blood contains approximately $50 \mathrm{mg}$ of iron. Thus, removal of only $2 \mathrm{~mL}$ of blood results in a $1 \mathrm{mg}$ loss of iron. ${ }^{17}$ If $450 \mathrm{~mL}$ of blood are taken in a donation, approximately $225 \mathrm{mg}$ of iron will be lost. If the donor has no iron deficiency, the RBCs and the $\mathrm{Hb}$ level will gradually return to normal within 3 to 4 weeks. Hence adequate iron stores are very important in the maintenance of donor health. ${ }^{18} \mathrm{An}$ acceptable frequency of donation is normally two to three times a year. In this study, all the regular donors had already donated two to three times within 3 months, because most of the blood donors always hide their identity and come in the guise of a patient relation to donate blood. This study did not estimate serum ferritin to define iron deficiency but the most recently published data indicate that most of these blood donors are iron deficient. Iron is a universal cofactor for mitochondrial energy generation and supports the growth and differentiation of all cell types. Systemic iron is regulated through the proteins transferrin (iron mobilization) and ferritin (iron sequestration). The physiologic importance of iron storage is that it provides a rapidly available supply in the event of blood loss. Serum ferritin concentration is an indicator of mobilizable body iron stores, ${ }^{19,20}$ and as such should be incorporated in donor screening.

Another significant and novel finding in this study is the prevalence of subclinical leukopenia of $12.5 \%$, which has never been reported before. The leukopenia was caused 
largely by a significant reduction in absolute lymphocyte counts as well as circulating lymphocytes. Granulocytes did not show any significant reduction between leukopenic and nonleukopenic groups. Circulating monocytes were equally reduced significantly in number in the leukopenic group while some red cell parameters such as $\mathrm{PCV}, \mathrm{RBC}, \mathrm{Hb}$, and $\mathrm{MCH}$ exhibited significant changes. Mean platelet volume in the leukopenic group was also significantly reduced. The reason for this leukopenia is not yet understood, especially as the process of erythropoeisis and leukopoesis does not originate from a common progeny. Whole blood transfusion usually means substitution of RBCs of the recipient from the donor. We are only concerned about the RBCs and not WBCs and platelets, probably because the life span for RBCs (which is 120 days) is long enough for them to be stored whereas the life span of WBCs and platelets is shorter.

For component preparation, concentrated WBCs or platelets can be prepared from pooled multiple donors, as is the current practice. Since subclinical leukopenia was observed in regular blood donors in this study, first-time donors must be the preferred donors for a greater yield of leukocytes. Herein lies the importance of this study. Choice of voluntary donors and first-time/family replacement donors has continued to be a challenge in the sub-Saharan African region due to commercial blood donors masquerading as family replacement donors. More stringent criteria for donor selection will help in the production of quality components for transfusion recipients in Nigeria. This study, however, does not postulate the existence of comorbid conditions with anemia, but instead represents an observation of a cross section of blood donors and provides a foundation for future studies.

The average adult male has about $7500 \mathrm{WBCs} / \mathrm{mm}^{3}$. This number may increase drastically following an infection and may decrease in people with an immunodeficiency disease such as AIDS. ${ }^{21} \mathrm{~A}$ low WBC count is referred to as leukopenia. Deficiency of all types of WBCs can be caused by bone marrow suppression; however, when there is selective reduction, the specific type of WBCs involved needs to be discussed. It should be noted that the donors were screened only for HIV and hepatitis B surface antigen. Other infectious agents or disease conditions that do not form part of our donor selection criteria may also lead to occult subclinical leukopenia. More studies on infectious agents and disease conditions (etiological factors) prevalent in our locality need to be undertaken to unravel the causes of this subclinical leukopenia.

A reduction in the number of lymphocytes in the blood is often referred to as lymphocytopenia or lymphopenia. This condition may result from bone marrow suppression that affects all types of blood cells, but there are also specific deficiencies of B- and T-cells. ${ }^{22}$ Lymphocytopenia may be caused by lack of the trace element zinc, long-term heavy alcohol consumption, and certain infectious diseases such as HIV, viral hepatitis, influenza, and tuberculosis. ${ }^{21,23}$ In addition, B- and T-cells may fail to differentiate from their common precursor cell. ${ }^{21}$

Granulocytes are a class of WBCs that contain granules of chemicals. The three types of granulocytes are neutrophils, eosinophils, and basophils. Mast cells are tissue-based cells related to basophils. Granulocytes are produced and stored in the bone marrow until they are released by cytokines. These cells defend against bacteria, fungi, parasites, and allergens. ${ }^{24}$

Since we have been unable to find any reports on the effect of blood donation on WBCs, it is difficult to corroborate the findings in this study; however, the significant reduction in lymphocyte counts among the leukopenic blood donors is an indication that their immune system may have been compromised. We recommend that regular eligibility screening for blood donation should include WBC counts, especially for those donating blood for component preparation of concentrated WBCs.

\section{Disclosure}

The authors report no conflicts of interest in this work.

\section{References}

1. World Health Organization. Regional blood safety initiative: A regional plan for blood safety (1998-2005). Geneva, Switzerland: World Health Organization; 1997:1-2

2. Mahinda VI, Bhatti A, Gupte SC. Iron status of regular voluntary blood donors, Asian J Transfus Sci. 2008;2:9-12.

3. Djalali M, Neyestani TR, Bateni J, Siassi F. The effect of repeated blood donations on the iron status of Iranian blood donors attending the Iranian blood transfusion organization. Int J Vitam Nutr Res. 2006; 76:132-137.

4. Mittal R, Marwaha N, Basu S, Mohan H, Ravi Kumar A. Evaluation of iron stores in blood donors by serum ferritin. Indian J Med Res. 2006; 124:641-646.

5. Jeremiah ZA, Koate BB. Anaemia, iron deficiency and iron deficiency anaemia among blood donors in Port Harcourt, Nigeria. Blood Transfus. 2010;8:113-117.

6. Jeremiah ZA, Koate BB. Reference percentiles of haematological and biochemical iron values of blood donors in Port Harcourt, Nigeria. Hematology. 2009;14:366-370.

7. NCCLS. How to define and determine reference intervals in the clinical laboratory; approved guideline -second edition. Wayne, PA: National Committee for Clinical Laboratory Standards, (2nd ed). C28-A2, 2000;20:13

8. Shaper AG, Lewis P. Genetic neutropenia in people of African Origin. Lancet. 1971;2:1021-1023.

9. Ezeilo GC. Non-genetic neutropenia in people of Africans. Lancet. 1972;2:1003-1004.

10. Badenhorst CJ, Fourie I, Steyn K, Looste PL, Lombard Cl, et al. The haematological profile of urban black Africans aged 15-64 years in the cape peninsula. East Afr Med J. 1995;72:19-24. 
11. Ezeilo GC. The aetiology of neuropenia in healthy Africans. East Afr Med J. 1974;51:936-942.

12. Pottgiesser T, Speckler W, Umhau M, Dickhuth HH, Roecker K, Schumacher YO. Recovery of hemoglobin mass after blood donation. Transfusion. 2008;48:1390-1397.

13. Blood donation. Hong Kong Red Cross Blood Transfusion Service. Available at: http://www.5.ha.org.hk/rcbts/edonation.html. Accessed 1 June, 2008

14. Before and after giving blood. Australia Red Cross Blood Service Available at: http://www.donaeblood.com.au/page.aspx?1DataTree Menu=48\&parent31. Accessed 1 June, 2008.

15. Donating whole blood. Lane Memorial Blood Bank. Available at: http:// www.imbb.org/wholeblood.html. Accessed 1 June, 2008.

16. Eller LA, Eller MA, Ouma B. Kataaha, P, Kyabaggu D, et al. Reference intervals in healthy adult Ugandan blood donors and their impact on conducting international vaccine trials. PLos ONE. 2008;3(12):e3919.

17. Ranney HM, Repaport SI. The red blood cell. In: Best and Taylor's Physiological Basis of Medical Practice. 12th ed. Baltimore, MD: Williams \& Wilkins; 1991:369-384.
18. Huetis DW. Busch S. Selection of blood donors. In: Practical Blood Transfusion. 2nd ed. Boston, MA: Little Brown and Company; 1976:7-48.

19. Finch CA, Huebers H. Perspective in iron metabolism. $N$ Engl J Med. 1982;306:1520-1528.

20. Milman N. Serum ferritin in Danes: studies of iron status from infancy to old age, during blood donation and pregnancy. Int $J$ Hematol. 1996;63:103-135.

21. Highleyman L. Government updates HIV treatment guidelines. BETA. 1999;12:3

22. Dailey J. Dailey's Notes on Blood Medical Consulting Group. Somerville, MA; 1993.

23. Tonnesen H, Andersen JR, Pedersen AE, Kaiser AH. Lymphopenia in heavy drinkers- reversibility and relation to the duration of drinking episodes. Ann Med. 1990;22:229-231.

24. Guyton A. Textbook of Medical Physiology. Unit IV: Blood cells, Immunity and Blood Clotting. Philadelphia, PA: WB Saunders \& Co; 1991.

\section{Publish your work in this journal}

The Journal of Blood Medicine is an international, peer-reviewed, open access, online journal publishing laboratory, experimental and clinical aspects of all topics pertaining to blood based medicine including but not limited to: Transfusion Medicine; Blood collection, Donor issues, Transmittable diseases, and Blood banking logistics; Immunohematology; Artificial and alternative

\section{Dovepress}

blood based therapeutics; Hematology; Biotechnology/nanotechnology of blood related medicine; Legal aspects of blood medicine; Historical perspectives. The manuscript management system is completely online and includes a very quick and fair peer-review system. Visit http://www.dovepress.com/ testimonials.php to read real quotes from published authors.

Submit your manuscript here: http://www.dovepress.com/Journal-of-blood-medicine-journal 